\title{
The portfolio resource in the development of the English writing process
}

\author{
DOI: https://doi.org/10.33262/ap.v3i2.1.47
}

\begin{abstract}
(c) (1) (8)(2)
El recurso del portafolio en el desarrollo del proceso de escritura en inglés
\end{abstract}

Gabriela del Rocío Armijos Ango. ', Alexandra del Rocío Saquinga Yanchapanta. ${ }^{2}$, Mónica Narciza Orbea Peñafiel. ${ }^{3} \&$ Luis Eduardo Burbano Santamaría. ${ }^{4}$

\begin{abstract}
.
Introduction. The portfolio is an educational resource widely applied in English learning process due to its versatility in compiling to evidence of a student's academic work. It also contributes to an exhaustive follow-up on the students' goals achievement and their skills development. Objective. The study points out the benefits of the portfolio in the development of the writing skill among students from A1 Starter level of the Universidad Técnica de Ambato during the academic semester September 2017 - February 2018. Methodology. During the research project a quantitative qualitative methodology was applied. Moreover, correlational variables helped to determine the students' deficiency in their writing process through the application of a pre-test and post-test. To obtain a significant sample of the research population four parallels belonging to A1 level were randomly selected with a total of 119 learners which were divided into experimental and control group. Results. After applying the evaluation instruments, the finding analysis

${ }^{1}$ Universidad Técnica de Ambato, Centro de Idiomas. Tungurahua, Ecuador, gd.armijos@uta.edu.ec, https://orcid.org/0000-0002-3630-0457

${ }^{2}$ Universidad Técnica de Ambato, Centro de Idiomas. Tungurahua, Ecuador, adr.saquinga@uta.edu.ec, https://orcid.org/0000-0003-2424-319X

${ }^{3}$ Universidad Técnica de Ambato, Centro de Idiomas. Tungurahua, Ecuador, mn.orbea@uta.edu.ec, https://orcid.org/0000-0003-1867-4671

${ }^{4}$ Universidad Técnica de Ambato, Centro de Idiomas. Tungurahua, Ecuador. le.burbano@uta.edu.ec, https://orcid.org/0000-0002-2063-0742
\end{abstract}


showed a meaningful improvement in the development of writing English skills in the experimental group over the control group. Conclusion. It was evident that portfolio's usage helps learners to be more aware and independent in their learning progress, this was reflected in their writing production.

Keywords: Portfolio, meaningful improvement, written production.

\section{Resumen.}

Introducción. El portafolio es un recurso educativo ampliamente aplicado en el proceso de aprendizaje del inglés debido a su versatilidad a la hora de recopilar las evidencias del trabajo académico del alumno. Además, contribuye a un seguimiento exhaustivo del cumplimiento de los objetivos de los alumnos y del desarrollo de sus competencias. Objetivo. El estudio señala los beneficios del portafolio en el desarrollo de la habilidad de escritura en estudiantes del nivel A1 Starter de la Universidad Técnica de Ambato durante el semestre académico septiembre 2017 - febrero 2018. Metodología. Durante el proyecto de investigación se aplicó una metodología cualitativa cuantitativa. Además, las variables correlacionales ayudaron a determinar la deficiencia de los estudiantes en su proceso de escritura a través de la aplicación de una prueba previa y posprueba. Para obtener una muestra significativa de la población investigada se seleccionaron aleatoriamente cuatro paralelos pertenecientes al nivel A1 con un total de 119 alumnos que se dividieron en grupo experimental y de control. Resultados. Tras la aplicación de los instrumentos de evaluación, el análisis de los resultados mostró una mejora significativa en el desarrollo de las habilidades de escritura en inglés en el grupo experimental con respecto al grupo de control. Conclusión. Es evidente que el uso del portafolio ayuda a los alumnos a ser más conscientes e independientes en su progreso de aprendizaje, lo que se refleja en su producción escrita.

Palabras claves: Portafolio, mejora significativa, producción escrita.

\section{Introduction.}

Nowadays, daily international communication is possible through English because it simplifies business and trades among different countries, which do not share a mutual mother tongue. In public education systems, English has an immense demand worldwide since it has become a requirement to international education access. Also, it has been making a notable influence in professional and personal life in the global development during last decades. (The English effect, 2013). In this sense, some academics such as: Alkhaldi, Davies, Timmis, Hann, Troncoso and Yong (2014) comment that English can provide people a sense of universal citizenship which is restrained to non-native speakers.

British Council (2013) estimated that two billion people worldwide speak English by different purposes. Correspondingly, Dearden (2014) highlighted that English is 
considered as the academic lingua franca what attracts people from all over the world, unfortunately not all students have the occasion to learn in English speaking real contexts, for that reason education has taken advantages from different sources and methodologies to increase quality in teaching languages. Jindapitak (2015) agrees with this statement and confirms that the number of non-native speakers is exceedingly over native, increasing the challenge during the acquisition of the fundamental skills.

Regarding this matter, some academics have different perspectives which underlying skills are more difficult to acquire. Harmer (2007) mentions that writing provides more thinking time to learners than other skills which include unprompted conversations. In addition, Likaj (2015) states the importance of writing in society development, considering the use of it in diverse aspects of the ordinary life such as: medical reports, academic essays, business letters, written advertisements, and e-mails, all these facets allow people language processing during the interaction. Furthermore, Aydoğan and Akbarov (2014) comment writing is a complex skill even for native speakers, because it includes graphic illustrations of language and presents opinions and thoughts in an ordered system.

In academic aspects, writing plays an important role during learners' advance. In this line, Puengpipattrakul (2014) considers that writing process provide learners a large quantity of tools to efficiently and methodically writings, due to the fact this skill implies the knowledge and application of an extensive grammar structures, vocabulary, and punctuation rules. The academic also remarks that process-oriented writing instructions face learners to the language accuracy and the same time it increases their motivation and confidence. Ali (2017) observes that sometimes writings are not successfully, and it can cause learners' frustration because students are unable to express their ideas in words appropriately. In relation to this aspect Lines (2014) concludes that writing is an intricate activity because learners must take into consideration singular features such as: knowledge about the topic, audience, and purpose, all of this will influence in the use of the appropriately grammar and vocabulary.

Considering the arguments provided by different academics, it was possible to determine the importance of the writing skill development in learners. Currently, there are diverse strategies and resources apply in English class hours to increase the skill mentioned. Nevertheless, this research study was based on the application of portfolios to support learners with the advancement of this skill, considering the benefits and expressive compensations during the learning process.

Nakayama (2012) mentions that portfolios can make the language progress more observable, which offers teachers a clear image of students' development. In this respect Melek and Hatice (2014) identify that portfolios donate fundamentals to the constructivist learning theory, because learners require a structure in their minds for each activity carries on, giving them a reflection about their advance. It is meaningful to mention that 
portfolios have the capacity to involve learners during the writing procedure, and stimulate them on their development as writers (Parsons \& Taylor, 2011)

\section{Metodologia.}

\section{Basic Method of Research}

The research was based on qualitative and quantitative approach. It is centered on the qualitative approach because this research project highlighted the human aspects of the educational improvement. Furthermore, it was also a quantitative approach because the analysis of statistical procedures was necessary.

As Walliman (2011) noted, a qualitative research is centered on people, who can be in social groups or as individuals. Students from level A1 played an important role in the development of this research project and thanks to them; it was possible to reach such conclusions. In addition, Patten (2005) clarifies that a qualitative research is usually based on published literature which includes reviews of them. In this study, bibliographic research about writing process development and portfolios was done to have a better idea about the variables of the project.

Otherwise, MacDonald and Headlam (2000) concluded that quantitative research focuses on data and analyzes results from a sample of the participants. A pre-test and a post-test were included during the process to have statistical data of the results gathered. Data examination is involved in this study because of the quantitative approach.

\section{Research Modality}

\section{Bibliographical -Documentary Research}

The information collected in this study was essential to have a better understanding about what other researchers have investigated on this study area. Additionally, Walliman (2011) puts a great importance on the development of bibliographical research due to the valuable data with different sources to reflect throughout a research project.

\section{Field Research}

It is a field research because this project was developed in the place where the problem presented took place. In this research project four A1 classes at the Language Center of Universidad Técnica de Ambato were considered to collect the information. Moreover, Walliman (2011) states that this type of research is fundamental to facilitate the data collection and analysis.

\section{Observational research}

This research is observational due to the direct analysis and exploration which can be done in the field of study. Additionally, being in contact with the behavior of the 
participants was an advantage because there was the opportunity to identify causes for the problem and look for strategies to help in the development of this project.

\section{Level or Type of Research}

\section{Correlational Research}

Due to the connection between the portfolios and the writing process, it was necessary to apply the correlational research. Moreover, being in contact with the problem into the real context was the main point for this project. Additionally, doing social or educational research in general demands an analysis of relationships among the direct variables. (Cohen, L., Manion, L. \& K. Morrison,2005).

\section{Quasi-experimental research}

It was quasi-experimental because the principal objective of this type of research was to find out the principles of study topics. Patten, (2016) mentions that experimental processes are used to discover reasons and consequences. Thus, the researcher considered essential the use of two sampling groups. The first group was controlled and the second one was experimental.

\section{Population and Sample}

The present research took place at public universities in higher education in Ambato. The participants in this research were from the A1 starter level.

\section{Population}

The entire population in the A1starter level at the Language Center of Universidad Técnica de Ambato was 1575 students in the semester September 2017 - February 2018.

\section{Method of Collection}

The present study took place at the Universidad Técnica de Ambato at the Languages Center, in which 119 students in their first English level were involved. The data was gathered through the application of a pre-test and a post-test to the experimental and control group. The results were analyzed and presented statistically at the end of the process. Furthermore, the portfolio as a class resource was employed during the academic period September 2017 - February 2018 with all the participants.

\section{Data Collection and Analysis}

As an activity of the pre-test the participants of the experimental and control group were asked to develop a short paragraph between 60 to 80 words about a topic determined by the academic. To evaluate the students' performance, a rubric was designed considering the parameters in formal evaluations over 20 points. The rubric mentioned was validated by the Academic Coordinator of the Languages Center. 
In addition, to collect data about students' progress during the process, another written paragraph was requested in the post-test using the rubric mentioned above. When all the data was gathered, the Student t-test was applied as a statistical analysis method.

\begin{tabular}{|c|c|c|c|c|c|c|c|}
\hline \multicolumn{4}{|c|}{ CONTROL GROUP } & \multicolumn{4}{|c|}{ EXPERIMENTAL GROUP } \\
\hline No. & Pre-Test & Post-Test & Differences & No. & Pre-Test & Post-Test & Differences \\
\hline 1 & 16 & 17 & 1 & 1 & 9 & 16 & 7 \\
\hline 2 & 15 & 18 & 3 & 2 & 13 & 20 & 7 \\
\hline 3 & 12 & 15 & 3 & 3 & 13 & 18 & 5 \\
\hline 4 & 14 & 16 & 2 & 4 & 8 & 19 & 11 \\
\hline 5 & 13 & 18 & 5 & 5 & 8 & 17 & 9 \\
\hline 6 & 15 & 16 & 1 & 6 & 10 & 14 & 4 \\
\hline 7 & 11 & 19 & 8 & 7 & 10 & 15 & 5 \\
\hline 8 & 8 & 15 & 7 & 8 & 8 & 9 & 1 \\
\hline 9 & 8 & 18 & 10 & 9 & 8 & 17 & 9 \\
\hline 10 & 14 & 15 & 1 & 10 & 10 & 18 & 8 \\
\hline 11 & 13 & 15 & 2 & 11 & 8 & 13 & 5 \\
\hline 12 & 13 & 13 & 0 & 12 & 15 & 18 & 3 \\
\hline 13 & 12 & 17 & 5 & 13 & 10 & 18 & 8 \\
\hline 14 & 12 & 14 & 2 & 14 & 14 & 19 & 5 \\
\hline 15 & 7 & 10 & 3 & 15 & 10 & 10 & 0 \\
\hline 16 & 14 & 17 & 3 & 16 & 8 & 15 & 7 \\
\hline 17 & 14 & 15 & 1 & 17 & 10 & 20 & 10 \\
\hline 18 & 14 & 15 & 1 & 18 & 15 & 20 & 5 \\
\hline 19 & 12 & 16 & 4 & 19 & 10 & 17 & 7 \\
\hline 20 & 12 & 16 & 4 & 20 & 8 & 18 & 10 \\
\hline 21 & 14 & 18 & 4 & 21 & 12 & 16 & 4 \\
\hline 22 & 12 & 9 & -3 & 22 & 8 & 14 & 6 \\
\hline 23 & 10 & 12 & 2 & 23 & 15 & 18 & 3 \\
\hline 24 & 12 & 12 & 0 & 24 & 10 & 13 & 3 \\
\hline 25 & 10 & 13 & 3 & 25 & 12 & 16 & 4 \\
\hline 26 & 9 & 12 & 3 & 26 & 8 & 13 & 5 \\
\hline 27 & 8 & 16 & 8 & 27 & 10 & 15 & 5 \\
\hline 28 & 12 & 15 & 3 & 28 & 10 & 16 & 6 \\
\hline 29 & 8 & 12 & 4 & 29 & 8 & 17 & 9 \\
\hline 30 & 8 & 8 & 0 & 30 & 9 & 16 & 7 \\
\hline- & - & - & - & 31 & 8 & 20 & 12 \\
\hline- & - & - & - & 32 & 9 & 11 & 2 \\
\hline- & - & - & - & 33 & 8 & 16 & 8 \\
\hline- & - & - & - & 34 & 12 & 18 & 6 \\
\hline- & - & - & - & 35 & 10 & 17 & 7 \\
\hline- & - & - & - & 36 & 8 & 15 & 7 \\
\hline
\end{tabular}




\begin{tabular}{|c|c|c|c|c|c|c|c|}
\hline - & - & - & - & 37 & 10 & 17 & 7 \\
\hline - & - & - & - & 38 & 18 & 20 & 2 \\
\hline - & - & - & - & 39 & 8 & 15 & 7 \\
\hline - & - & - & - & 40 & 15 & 16 & 1 \\
\hline - & - & - & - & 41 & 15 & 14 & -1 \\
\hline - & - & - & - & 42 & 8 & 16 & 8 \\
\hline- & - & - & - & 43 & 8 & 10 & 2 \\
\hline - & - & - & - & 44 & 8 & 14 & 6 \\
\hline - & - & - & - & 45 & 15 & 19 & 4 \\
\hline- & - & - & - & 46 & 8 & 10 & 2 \\
\hline - & - & - & - & 47 & 8 & 10 & 2 \\
\hline - & - & - & - & 48 & 13 & 19 & 6 \\
\hline - & - & - & - & 49 & 8 & 14 & 6 \\
\hline - & - & - & - & 50 & 15 & 18 & 3 \\
\hline- & - & - & - & 51 & 16 & 19 & 3 \\
\hline - & - & - & - & 52 & 8 & 19 & 11 \\
\hline - & - & - & - & 53 & 8 & 18 & 10 \\
\hline- & - & - & - & 54 & 12 & 16 & 4 \\
\hline- & - & - & - & 55 & 8 & 14 & 6 \\
\hline - & - & - & - & 56 & 10 & 14 & 4 \\
\hline- & - & - & - & 57 & 10 & 20 & 10 \\
\hline - & - & - & - & 58 & 10 & 19 & 9 \\
\hline - & - & - & - & 59 & 15 & 18 & 3 \\
\hline - & - & - & - & 60 & 8 & 14 & 6 \\
\hline - & - & - & - & 61 & 15 & 19 & 4 \\
\hline - & - & - & - & 62 & 8 & 16 & 8 \\
\hline - & - & - & - & 63 & 18 & 19 & 1 \\
\hline - & - & - & - & 64 & 7 & 10 & 3 \\
\hline - & - & - & - & 65 & 13 & 19 & 6 \\
\hline - & - & - & - & 66 & 8 & 18 & 10 \\
\hline - & - & - & - & 67 & 5 & 17 & 12 \\
\hline- & - & - & - & 68 & 10 & 18 & 8 \\
\hline- & - & - & - & 69 & 4 & 14 & 10 \\
\hline - & - & - & - & 70 & 5 & 16 & 11 \\
\hline - & - & - & - & 71 & 5 & 13 & 8 \\
\hline - & - & - & - & 72 & 5 & 18 & 13 \\
\hline - & - & - & - & 73 & 5 & 16 & 11 \\
\hline - & - & - & - & 74 & 5 & 13 & 8 \\
\hline - & - & - & - & 75 & 5 & 15 & 10 \\
\hline - & - & - & - & 76 & 15 & 19 & 4 \\
\hline- & - & - & - & 77 & 16 & 18 & 2 \\
\hline- & - & - & - & 78 & 5 & 11 & 6 \\
\hline
\end{tabular}




\begin{tabular}{llllllll}
\hline- & - & - & - & 79 & 5 & 12 & 7 \\
- & - & - & - & 80 & 5 & 14 & 9 \\
- & - & - & - & 81 & 5 & 16 & 11 \\
- & - & - & - & 82 & 5 & 16 & 11 \\
- & - & - & - & 83 & 16 & 20 & 4 \\
- & - & - & - & 84 & 12 & 18 & 6 \\
- & - & - & - & 85 & 14 & 17 & 3 \\
- & - & - & - & 86 & 7 & 15 & 8 \\
- & - & - & - & 87 & 10 & 18 & 8 \\
- & - & - & - & 88 & 8 & 18 & 10 \\
- & - & - & - & 89 & 4 & 9 & 5 \\
\hline
\end{tabular}

Table 1. Data collection control and experimental group.

Source. From "The portfolio as a resource aimed at the development of the English writing process in higher education," by Armijos, 2018. Repositorio Institucional Universidad Técnica de Ambato, (https://repositorio.uta.edu.ec/simple-search?query=Gabriela+armijos).

\section{Results.}

After comparing the data gathered through the statistical graphics and tables, it was possible to observe that the application of portfolios in the experimental group allowed participants to acquire better outcomes in writing process and improve their language practice according to their English level. Furthermore, during the study and the application of the resource chosen, students were able to foster their originality when they write compared with the control group which a traditional teaching methodology was used.

\begin{tabular}{|c|c|c|c|c|c|}
\hline \multicolumn{6}{|c|}{ Paired sample statistics } \\
\hline & & Mean & $n$ & $\begin{array}{l}\text { Standard } \\
\text { deviation }\end{array}$ & $\begin{array}{l}\text { Standard error } \\
\text { of the mean }\end{array}$ \\
\hline \multirow{3}{*}{$\begin{array}{l}\text { Control } \\
\text { group }\end{array}$} & $\begin{array}{l}\text { Pre-test } \\
\text { Total }\end{array}$ & 11.73 & 30 & 25.042 & 0.4572 \\
\hline & $\begin{array}{l}\text { Post-test } \\
\text { Total }\end{array}$ & 14.73 & 30 & 27.660 & 0.5050 \\
\hline & $\begin{array}{l}\text { Differences } \\
\text { (Pre-Post) }\end{array}$ & 3.00 & 30 & 27.165 & 0.49596 \\
\hline \multirow{3}{*}{$\begin{array}{l}\text { Experimental } \\
\text { group }\end{array}$} & $\begin{array}{l}\text { Pre-test } \\
\text { Total }\end{array}$ & 9.76 & 89 & 34.871 & 0.3696 \\
\hline & $\begin{array}{l}\text { Post-test } \\
\text { Total }\end{array}$ & 16.03 & 89 & 28.661 & 0.3038 \\
\hline & $\begin{array}{l}\text { Differences } \\
\text { (Pre-Post) }\end{array}$ & 6.27 & 89 & 31.253 & 0.3313 \\
\hline
\end{tabular}

Table 2. Student $t$ test results.

Source. From "The portfolio as a resource aimed at the development of the English writing process in higher education," by Armijos, 2018. Repositorio Institucional Universidad Técnica de Ambato, (https://repositorio.uta.edu.ec/simple-search?query=Gabriela+armijos). 


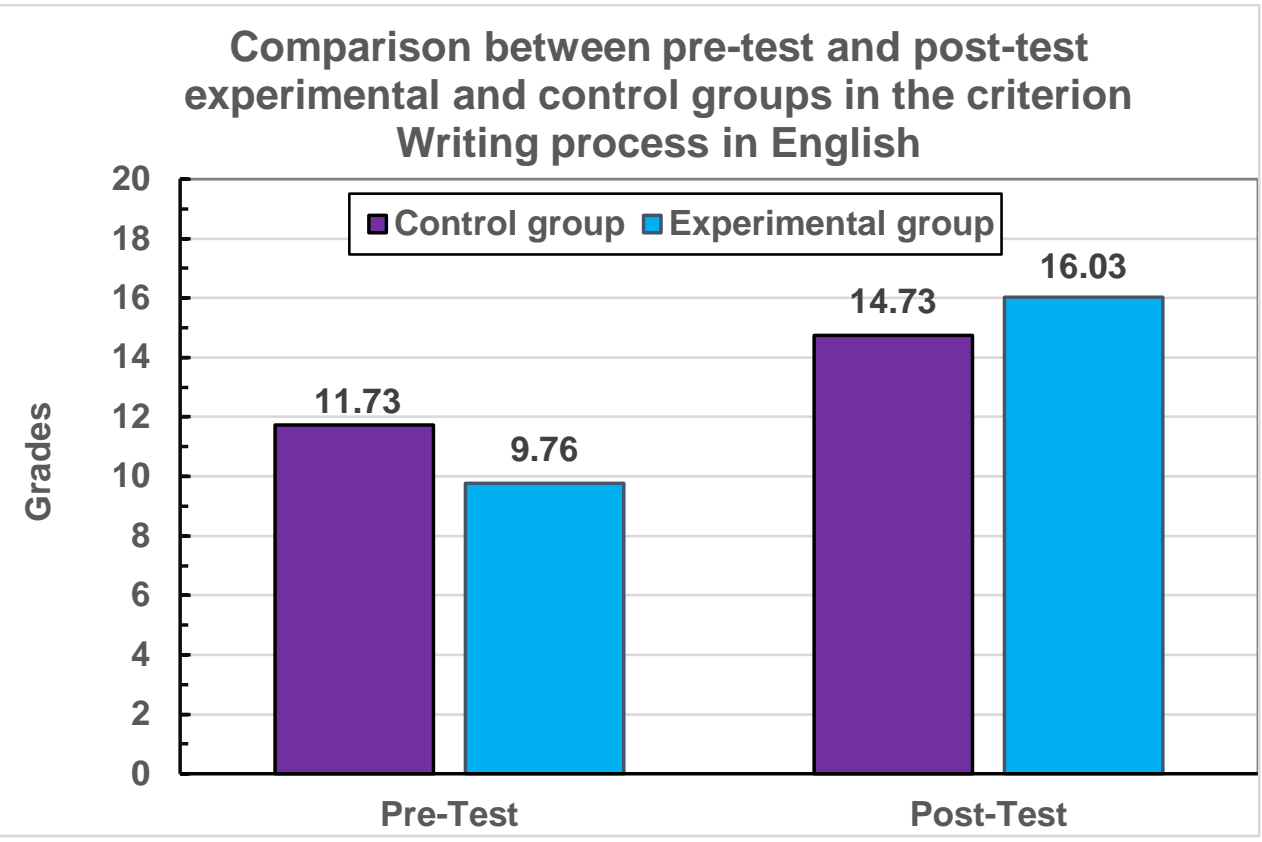

Graph 1. Mean pre-test and post-test experimental and control groups.

Source. From "The portfolio as a resource aimed at the development of the English writing process in higher education," by Armijos, 2018. Repositorio Institucional Universidad Técnica de Ambato, (https://repositorio.uta.edu.ec/simple-search?query=Gabriela+armijos).

The table showed that differences in the results obtained are more significant in the experimental than in the control group.

\begin{tabular}{|c|c|c|c|c|c|c|c|c|c|}
\hline \multicolumn{10}{|c|}{ Paired sample statistics } \\
\hline \multirow[b]{4}{*}{ 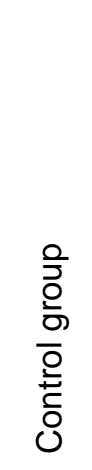 } & & \multicolumn{5}{|c|}{ Paired differences } & \multirow{3}{*}{$\mathrm{T}$} & \multirow{3}{*}{$\mathrm{df}$} & \multirow{3}{*}{$\begin{array}{c}\text { Sig. } \\
\text { (unilateral) }\end{array}$} \\
\hline & & \multirow[t]{2}{*}{ Mean } & \multirow[t]{2}{*}{$\begin{array}{l}\text { Standard } \\
\text { deviation }\end{array}$} & \multirow{2}{*}{$\begin{array}{l}\text { Standard } \\
\text { error of } \\
\text { the mean }\end{array}$} & \multicolumn{2}{|c|}{$\begin{array}{l}95 \% \text { of difference } \\
\text { interval of } \\
\text { confidence }\end{array}$} & & & \\
\hline & & & & & Lower & Upper & & & \\
\hline & $\begin{array}{l}\text { Pre- } \\
\text { test } \\
\text { Total - } \\
\text { Post- } \\
\text { test } \\
\text { Total }\end{array}$ & 3.00 & 2.716 & 0.496 & 1.986 & 4.014 & 6.049 & 29 & 0.0000005 \\
\hline 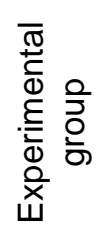 & $\begin{array}{l}\text { Pre- } \\
\text { test } \\
\text { Total - } \\
\text { Post- } \\
\text { test } \\
\text { Total }\end{array}$ & 6.270 & 3.125 & 0.331 & 5.611 & 6.928 & 18.926 & 88 & $4,50 \mathrm{E}-29$ \\
\hline
\end{tabular}




\section{Final decision}

The $t$ calculated results showed the application of portfolios as a written resource increase students' development in their writing procedure and tasks.

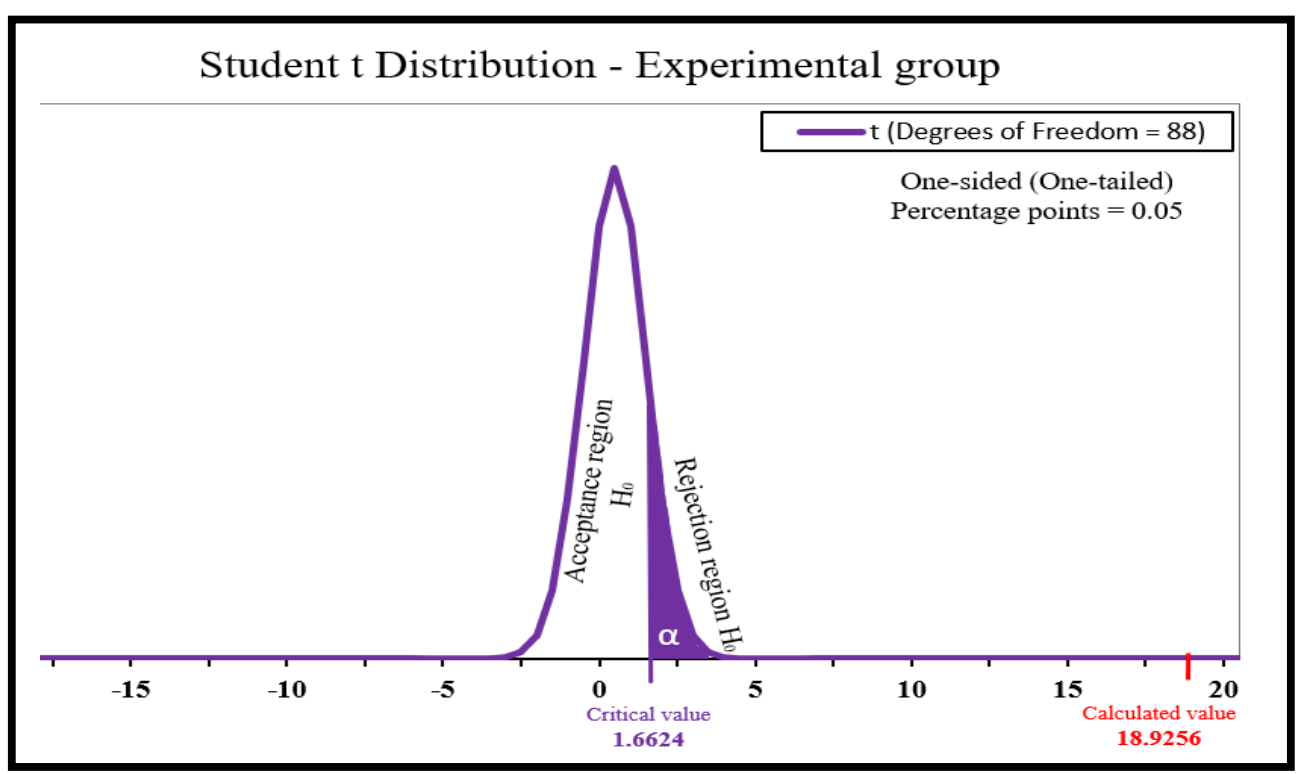

Graph 2. Student t-test distribution experimental group.

Source. From "The portfolio as a resource aimed at the development of the English writing process in higher education," by Armijos, 2018. Repositorio Institucional Universidad Técnica de Ambato, (https://repositorio.uta.edu.ec/simple-search?query=Gabriela+armijos).

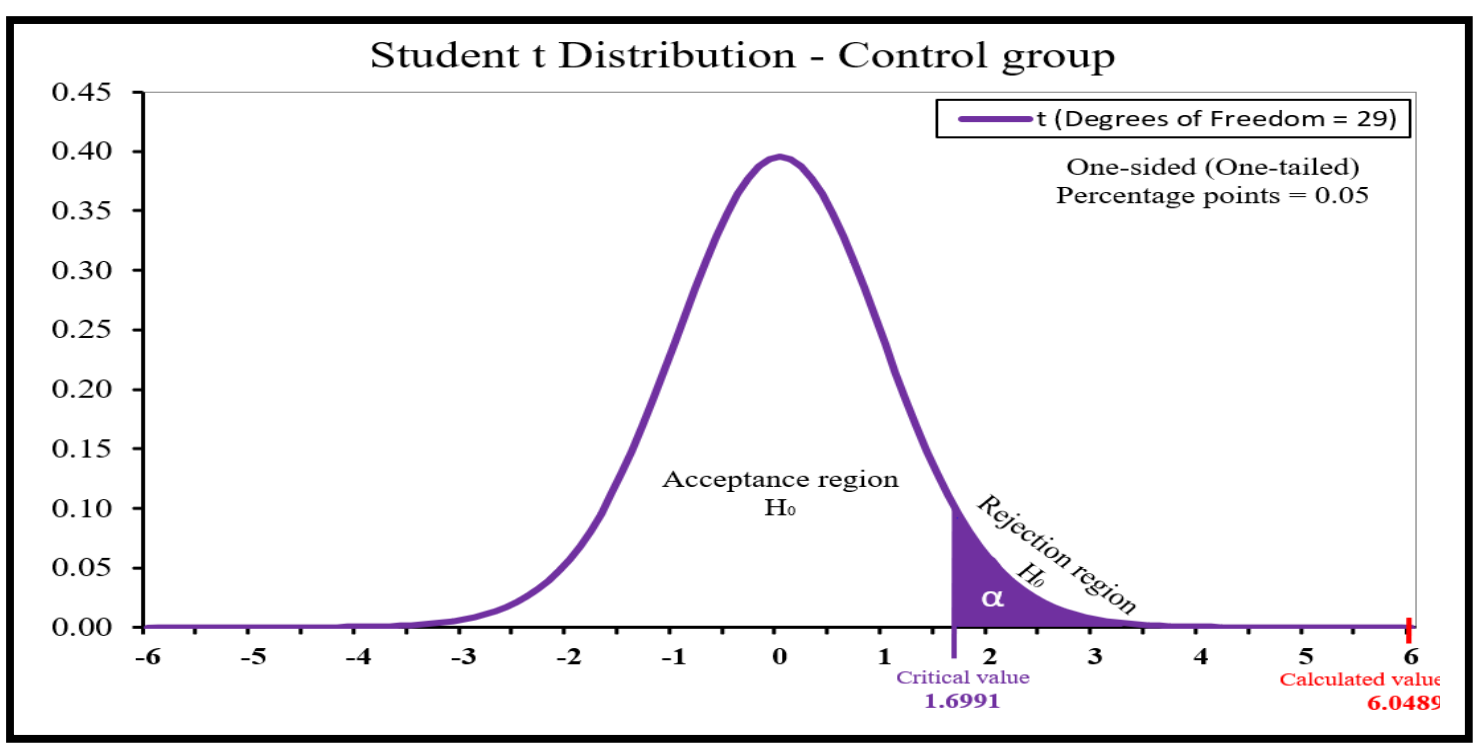

Graph 3. Student t-test distribution control group

Source. From "The portfolio as a resource aimed at the development of the English writing process in higher education," by Armijos, 2018. Repositorio Institucional Universidad Técnica de Ambato, (https://repositorio.uta.edu.ec/simple-search?query=Gabriela+armijos).

\section{Discussion.}

The primary purpose of this study was to establish if the use of portfolios in the English classroom improves the development of the writing process. To verify this statement a 
pre-test and a post-test were developed. The results of the tests showed the benefits of the use of portfolios in the development of the writing skill since students had the opportunity to use a different teaching methodology. Furthermore, students were able to monitor their learning and improvement when they used their portfolios. As it was mentioned by Nakayama (2012) portfolios make the language improvement more noticeable, which offers teachers a clear image of students' development.

During this study, the progress of the writing skill in A1 English students at Universidad Técnica de Ambato was observable. The use of portfolios contributed to this progress. Moreover, learners were involved in the writing procedure (Parsons \& Taylor, 2011). For this reason, it is crucial to use portfolios with a purpose because they provide considerable feedback for teachers as well as pupils. On the other hand, it is essential to mention that to appreciate all these benefits students and teachers must be involved in a long-term process.

\section{Conclusions.}

- Through the application of the pre-test was possible to identify participants' weaknesses in the use of English Language in A1 level and poor development in their writing skill. This fact promoted the use of portfolios in which the participants could acquire the knowledge about the elementary writing components such as punctuation, capitalization, spelling, grammar (according to their level of study) and formatting mistakes. The percentage of the progress was evidenced in the post-test results.

- Diverse types of writing tasks were done by students during the class hour with the purpose of involving participants in the writing process. The writing process in each task covers different stages which allowed participants to be awareness of the application of a systematic method of ideas and paragraphs. Every student was responsible to gather all the writing assignments in a portfolio, which allowed to register and control students' advance. After the revision of each portfolio was possible to notice students had better achievements in topics related to themselves written in blogs, e-mails, and journals.

- A post-test was applied to confirm the students' progress in writing using portfolios. The control group got 14.73 and the experimental group 16.03. The results showed the experimental group improved their writing skill over the control group, also it is evident the use of portfolios increased students' participation during the process at the same time increasing their writing micro skills. 


\section{References.}

Abreus, A., \& Hernández, P. (2016). Nuevos retos para la Enseñanza del Inglés en la Universidad Ecuatoriana actual. Revista Electrónica Formación y Calidad Educativa (REFCalE), n 3 , vol 4.

Ali, K. (2017). Learning and Teaching in English: A Case Study of Higher Education in Libya. Submitted for degree of Doctor of Philosophy, Liverpool John Moores University.

Alkhaldi, A., Davies, B., Timmis, I., Hann, N., Troncoso, C., \& Yi, Yong. (2014). The impact of English on learners' wider lives: British Council. London

Armijos, G. (2018). The portfolio as a resource aimed at the development of the English writing process in higher education. [Master's thesis, Universidad Técnica de Ambato]. Repositorio Institucional Universidad Técnica de Ambato. https://repositorio.uta.edu.ec/simple-search?query=Gabriela+armijos

Aydoğan, H., \& Akbarov, A. (2014). The Four Basic Language Skills, Whole Language \& Integrated Skill Approach in Mainstream University Classrooms in Turkey. Mediterranean Journal of Social Sciences $\mathrm{n}^{\circ}$, vol 5.

British Council. (2013). The English Effect, London.

British Council. (2015). English in Ecuador: An examination of policy, perceptions and influencing factors", Quito.

Brown. (2001). Teaching by Principles and Interactive Approach to Language. New York: Pearson Education.

Brown. (2001). Language Assessment. New York: Pearson Education.

Cohen, L., Manion, L., \& Morrison, K. (2005). Research Methods in Education. ( $^{\text {th }}$ ed.). London: RoutledgeFalmer.

Dearden, J. (2014). English as a medium of instruction - a growing global phenomenon: British Council. London.

Harmer, J. (1998). How to teach English. Harlow: Pearson Education Limited, (1 ${ }^{\text {st }}$ ed).

Harmer, J. (2007). How to teach English. Harlow: Pearson Education Limited, (3 ${ }^{\text {rd }}$ ed.)

Harmer, J. (2001). The practice of English Language Harlow: Pearson Education Limited, ( $3^{\text {rd }}$ ed.). 
Jindapitak, N. (2015). English as a Lingua Franca: Learners' Views on Pronunciation. Electronic Journal Electronic Journal of Foreign Language Teaching $\mathrm{n}^{\circ} 2$, vol.12:260-275.

Likaj, M. (2015). Teaching Writing Through Communicative Approach In Military English. Journal of Education and Practice $\mathrm{n}^{\circ}$ 20, vol. 6: 102-107.

Lines, H. (2014). It's a matter of individual taste, I guess: Secondary school for English teachers' and students' conceptualizations of quality in writing. Submitted degree of Doctor of Philosophy in Education, Exeter University.

Mak, P. \& Wong, K. (2017). Self-regulation through portfolio assessment in writing classrooms. ELT journal: An international journal for teachers of English to speakers of other languages $\mathrm{n}^{\mathrm{o}} 1$, vol. 72, $2018: 49-61$.

Melek, D., \& Hatice, D. (2014). The Use of Portfolio in English Language Teaching and its Effects on Achievement and Attitude. Procedia-Social and Behavioral Sciences. $n^{\circ} 191: 2634-2640$.

Nakayama, K. (2012). A case study to make language learning more visible at a Japanese Senior High School”, Waseda University 185-190.

North Carolina Department of Public Instruction, Second Languages (1999). Assessment, Articulation, an Accountability: North Carolina.

Nunan, D. (2015). Teaching English to Speakers of Other Languages: An Introduction. New York: Routledge.

Ok, S. (2017). Reflections of ELT Students on Their Progress in Language and Vocabulary Use in Portfolio Process. Electronic Journal of Foreign Language Teaching. $\mathrm{n}^{\circ}$ 2, vol 14: 187-200.

Parsons, J., \& Taylor, L. (2011). Improving Student Engagement. Current Uses in Education. ${ }^{\circ}$ 1, vol. 14:1-32.

Puengpipattrakul, W. (2014). A Process Approach to Writing to Develop Thai EFL Students' Socio-Cognitive Skills. Electronic Journal of Foreign Language Teaching. $\mathrm{n}^{\circ} 2$, vol 11:270-284.

Richards \& Rodgers. (1999). Approaches and Methods in Language Teaching. Cambridge: Cambridge University Press.

Richards \& Schmidt. (2010). Longman Dictionary of Language Teaching and Applied Linguistics (forth ed.). Edinburgh: Pearson Education Limited. 
UNICEF. (2013). Documento de Sistematización de la Experiencia Más allá de lo Imaginado Período 2001-2013. Ecuador. 


\section{Para citar el artículo indexado}

Armijos Ango, G. del R., Saquinga Yanchapanta, A. del R., Orbea Peñafiel, M. N., \& Burbano Santamaría, L. E. (2021). The portfolio resource in the development of the English writing process. AlfaPublicaciones, 3(2.1), 27-41. https://doi.org/10.33262/ap.v3i2.1.47

\section{Ciencia
Digital
Edtatzal}

El artículo que se publica es de exclusiva responsabilidad de los autores y no necesariamente reflejan el pensamiento de la Revista Alpha Publicaciones.

El artículo queda en propiedad de la revista y, por tanto, su publicación parcial y/o total en otro medio tiene que ser autorizado por el director de la Revista Alpha Publicaciones.
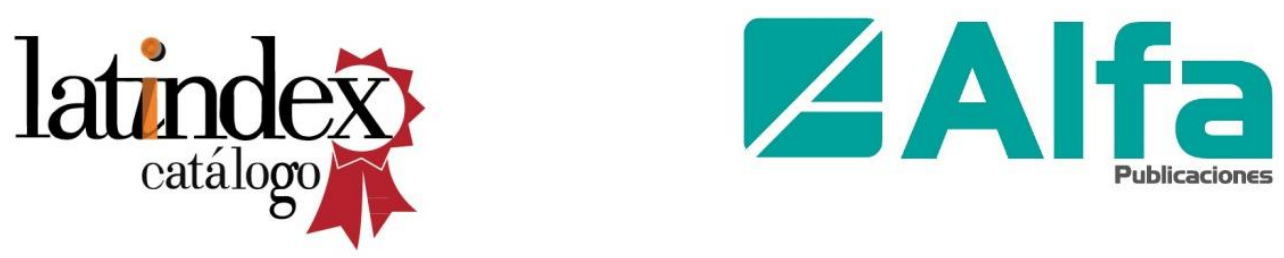